\title{
ИРКУТСКИЙ ПЕРИОД В ЖИЗНИ АКАДЕМИКА БАЗАРЫН ШИРЕНДЫБА
}

\author{
А. П. Суходолов ${ }^{1}$, Ю. В. Кузьмин ${ }^{1}$, В. В. Куфтарева² \\ ${ }^{1}$ Байкальский государственный университет, г. Иркутск, Российская Федерация \\ 2 Педагогический институт, Иркутский государственный университет
}

Информация о статье
Дата поступления
17 мая 2017 г.
Дата принятия к печати
2 июня 2017 г.
Дата онлайн-размещения
15 сентября 2017 г.
Ключевые слова
История; историография;
российско-монгольские
отношения; иркутский период;
биография;
Базарын Ширендыб;
М. А. Гудошников; Н. Н. Козьмин;
Ф. А. Кудрявцев; Г. Ф. Кунгуров;
С. В. Шостакович

\begin{abstract}
Аннотация
В статье идет речь об иркутском периоде жизни известного монгольского ученого, историка, публициста академика Базарын Ширендыба. Дается информация о его студенческой жизни в 1930-1940-е гг., об обстоятельствах становления личности, о формировании профессиональных интересов. В тесной взаимосвязи с историей иркутских вузов, жизнью города и страны рассматривается история Иркутского педагогического института в 1930-1940-е гг. Приводятся сведения о работе педагогического коллектива, об известных преподавателях пединститута (М. А. Гудошников, Н. Н. Козьмин, Ф. А. Кудрявцев, Г. Ф. Кунгуров, С. В. Шостакович), а также говорится об изменениях в жизни города летом 1941 г.
\end{abstract}

\section{IRKUTSK PERIOD IN THE LIFE OF ACADEMICIAN BAZARYN SHIRENDYB}

\author{
Alexander P. Sukhodolov', Yuri V. Kuzmin', Venera V. Kuftareva \\ ${ }^{1}$ Baikal State University, Irkutsk, Russian Federation \\ ${ }^{2}$ Pedagogical Institute, Irkutsk State University, Russian Federation
}

\author{
Article info \\ Received \\ May 17, 2017 \\ Accepted \\ June 2, 2017 \\ Available online \\ September 15, 2017 \\ Keywords \\ History; historiography; Russian- \\ Mongolian relations; Irkutsk \\ period; biography; Bazaryn \\ Shirendyb; M. A. Gudoshnikov; \\ N. N. Kozmin; F. A. Kudryavtsev; \\ G. F. Kungurov, S. V. Shostakovich
}

\begin{abstract}
The article is dedicated to the Irkutsk period in the life of the famous Mongolian scientist, publicist, historian, academician Bazaryn Shirendyb. The authors write about his student life in the 1930s-1940s, about the circumstances of the formation of B. Shirendyb's personality, about the formation of his professional interests. The history of the Irkutsk Pedagogical Institute in the 1930s-1940s is studied as closely connected with the history of Irkutsk universities, the life of the city and the country. There is some information about the work of the teaching staff, about the well-known teachers of the Pedagogical Institute (M. A. Gudoshnikov, N. N. Kozmin, F. A. Kudryavtsev, G. F. Kungurov, S. V. Shostakovich). The authors also write about the changes in the life of the city in the summer of 1941.
\end{abstract}


Иркутск - один из российских центров подготовки специалистов для дружественной Монголии. Наш город географически и исторически близок Монголии. Опыт в подготовке кадров и изучении соседней страны насчитывает трехвековую историю. Уже в 1700-е гг. была озвучена проблема отсутствия знаний языка и культуры соседнего народа, что, разумеется, не только затрудняло международные контакты и не прибавляло авторитета православным первопроходцам, но и, наоборот, давало преимущества католическим миссионерам. Исходя из этого, с 1725 по 1746 г. в Иркутске, при Воскресенском монастыре, была открыта и успешно работала русско-мунгальская школа - первое учебное заведение, где в России изучался монгольский язык [1, с. 42].

Традиции, заложенные в те годы и приумноженные за два столетия, позволили Иркутску стоять на одной ступени с признанными научными центрами монголоведения. В этом кроется одна из причин, по которой его выбирали в качестве места для подготовки национальных кадров Монголии в разные периоды истории. Например, в 1914-1917 гг. вместе с группой юношей-монголов в Иркутском учительском институте обучался Хорлогийн Чойбалсан - будущий политический лидер Монголии. А в конце 1930-х гг. в Иркутске оказалась группа молодых монголов, которые составили политическую, экономическую и научную элиту Монголии второй половины XX в.

Академик Базарын Ширендыб (19122001) - известный монгольский ученый, историк, публицист. С 1937 по 1941 г. являлся студентом-историком в Иркутском педагогическом институте. Позднее, с 1941 по 1944 г., был референтом премьер-министра MHP X. Чойбалсана по вопросам культуры и просвещения. Со дня основания в 1942 г. и на протяжении 11 лет возглавлял Монгольский государственный университет. С 1961 по 1982 г. занимал должность первого президента Академии наук МНР. Наибольшее количество работ посвятил истории Монгольской народной революции 1921 г. На эту тему им защищены кандидатская [2] и докторская [3] диссертации.

В 1930-е гг. в МНР озаботились формированием нового поколения интеллигенции, не знавшей, по словам самого академика Б. Ширендыба, «революционного террора и репрессий». На руководящие посты стали выдвигать «молодых» специалистов, подготовка которых велась в СССР иГермании, по- скольку в МНР в это время высшие учебные заведения отсутствовали.

Согласно подписанному в 1929 г. соглашению «Об основных принципах взаимоотношений между СССР и MНР» ${ }^{1}$, Советский союз оказывал помощь в подготовке специалистов для Монголии. В СССР создавались учебные заведения, в которых обучалась монгольская молодежь [4; 5, с. 29]. Выпускники организованных рабфаков становились студентами советских вузов. Немало известных личностей Монголии обучалось в Иркутске. Монголы называют Иркутск «вратами знаний». Этот город стал кузницей кадров для соседней страны [6, с. 2]. Многие монгольские специалисты прошли подготовку непосредственно в стенах Иркутского педагогического института. Одним из таких людей был будущий академик Базарын Ширендыб [7, с. 42; 8-10]. Иркутский период жизни Б. Ширендыба малоизучен в современной монгольской и российской историографии, в связи с этим нами предпринята попытка восполнить пробел в данной части его биографии.

Прежде чем оказаться в Иркутске, Б. Ширендыб длительное время учился в Монголии: сначала в буддийском монастыре Нухт, затем в светской школе-интернате недалеко от этого монастыря, после в сельскохозяйственной школе в Цэцэрлэге и Улан-Баторе, а программу старших классов он осваивал на Улан-Удэнском монголрабфраке с 1932 по 1937 г. ${ }^{2}$

По воспоминаниям Б. Ширендыба, большим событием для него во время учебы в Улан-Удэ были поездки в Москву и Ленинград, оставившие «неизгладимое» впечатление $[11$, с. 82; 12]. После второй поездки в Москву Ширендыб должен был определиться со своей будущей профессией. Монголии необходимы были специалисты для развития драматического искусства, поэтому министерство просвещения МНР рекомендовало ему поступить на режиссерский фракультет Государственного института театрального искусства им. А. В. Луначарского.

После визита к А. Д. Фурмановой Б. Ширендыб сделал окончательный выбор [13]. По его словам, он понял, что «должен, прежде всего, понять сущность и закономерность явлений, что ему еще рано думать о режиссуре и самостоятельной постановке спектаклей» [11, с. 82-83]. Поэтому Б. Ширендыб

${ }^{1}$ Советско-монгольские отношения, 1921-1974: документы и материалы. М. : Улан-Батор, 1970. Т. 1 : 1921-1940.

2 Государственный архив Иркутской области (ГАИО). Ф. р-842. Оп. 84. Д. 4176. Л. 3. 
был командирован в Иркутский пединститут ${ }^{3}$ и зачислен без «вступительных испытаний» ${ }^{4}$. Под вступительными испытаниями стоит понимать «экзамены по русскому языку, истории СССР, математике и географии» [7, с. 42].

Описание условий жизни студентов и событий в жизни вузов в ту эпоху даст представление об Иркутском пединституте в период учебы Б. Ширендыба, позволит нам понять атмосферу, в которой пребывало студенчество конца 1930-х — начала 1940-х гг.

В городе в тот период проходили парады, смотры, соревнования, автопробеги и мотокроссы, демонстрации, выставки, премьеры спектаклей, митинги, праздничные народные гуляния, гастроли известных творческих коллективов ${ }^{5}$. В эти годы в Иркутске произошли значительные преобразования 6 . Открывались новые школы, дома творчества, стадионы, магазины, общественные столовые. Кроме того, в Иркутске в 1930-е гг. появилось несколько высших учебных заведений - горный, педагогический, медицинский, финансово-экономический институты, три последних вышли из состава Иркутского университета.

Жизнь вузов была тесно переплетена с жизнью города. Студенты принимали участие в парадах физкультурников, в общегородских собраниях студенческого актива и научных работников высших учебных заведений Иркутска, в стрелковых соревнованиях к годовщине создания Красной Армии, в межвузовских социалистических соревнованиях и олимпиадах, оказывали большую помощь в антирелигиозной пропаганде. Не прошли для города незаметно внешнеполитические события 1930-х гг.: военные события в Китае

${ }^{3}$ ГАИО. Ф. р-842. Оп. 84. Д. 4176. Л. 1.

4 «Предъявитель сего гражданин Монгольской народной республики Шириндык Базаров, окончивший в 1937 г. Монголрабфак по всем предметам с отметкой "отлично» действительно командируется в Иркутский педагогический институт. Согласно существующего положения Ширендык Базаров, как отличник, имеет право поступить в вуз без испытаний».

${ }^{5}$ В частности, устраивалась передвижная выставка картин Третьяковской галереи; в сентябре 1938 г. прибыл на гастроли Краснознаменный ансамбль песни и пляски Красной Армии под руководством А. В. Александрова; в ноябре 1938 г. в цирке были гастроли Юрия Дурова с группой животных.

${ }^{6}$ Среди них особо стоит отметить реконструкцию бывшего Иерусалимского кладбища в парк культуры и отдыха; строительство трамвайного сообщения в Иркутске; открытие регулярного воздушного сообщения Иркутск - Москва; открытие Памятника борцам революции; организацию археологической экспедиции А. П. Окладникова в район села Буреть; наладку регулировки уличного движения, вызванную интенсивностью автомобильного потока в городе; строительство деревянного здания цирка «Шапито».

${ }^{7}$ URL: https://www.oldgazette.ru/pravda/0303 1938.
У озера Хасан, на Халхин-Голе ${ }^{8}$, вторжение Германии в Польшу.

Подробнее хотелось бы остановиться на истории развития Иркутского пединститута и работе преподавательского состава в период учебы Б. Ширендыба. Он признавал, что педагоги вуза оказали огромное влияние на становление его как историка. Представляется, что иркутская историческая школа соормировала будущего историка, академика, создателя концепции современной истории Монголии XX в.

В педагогическом институте в 1938 г. обучалось около тысячи человек. С 1939 г. во главе его стоял Николай Григорьевич Прозоровский (1901-1967), доцент, кандидат экономических наук. В этой должности он находился до 1961 г. [14]. Преподаватели принимали участие в межвузовских, общегородских семинарах, в программах ликвидации неграмотности и обучения малограмотных, вели занятия в университете выходного дня, выступали на заседаниях комиссий, комитетов, участвовали в мероприятиях города9. Профрессора, доценты и преподаватели выезжали в совхозы и на предприятия области для чтения лекций и научно-популярных докладов.

В довоенный период в пединституте значительно расширилась научная работа: опубликовано более 300 научных трудов, регулярными стали «Ученые записки», создан фундаментальный труд М. П. Алексеева «Сибирь в известиях западноевропейских путешественников и писателей». Также не остались без внимания молодого монгольского исследователя работы историков М. А. Гудошникова, В. П. Денисова, Ф. А. Кудрявцева, Н. Н. Козьмина ${ }^{10}$, язы-

8 На Иркутском авиазаводе комплектовали экипажи и самолеты в летную группу для Китая. В связи с событиями в Монголии Иркутский завод им. И. Сталина стал прифронтовым предприятием и перешел на выпуск новых и ремонт поврежденных в боях на Халхин-Голе самолетов для Красной Армии.

9 Например, в вечере памяти В. В. Маяковского, организованном в Доме культуры профсоюзов, принимали участие Г. Кунгуров, К .Седых и А. Кузнецов, которые поделились воспоминаниями о встречах с поэтом, а на открытии родительского университета доклад «Права и обязанности родителей по отношению к детям» сделала доцент Иркутского пединститута Е. И. Недоспасова.

10 Николай Николаевич Козьмин - профессор Иркутского пединститута, сотрудник Восточно-Сибирского облисполкома, крупный исследователь Сибири. Арестован 23 августа 1937 г. органами НКВД по делу «О белогвардейской контрреволюционной организации», возникшей в 1920 г., которой инкриминировались ведение шпионажа в пользу Японии и связь с японской контрразведкой. Была ликвидирована в 1937-1938 гг. Н. Н. Козьмину было предъявлено обвинение по ст. 58 УК РСФСР. Скончался после конвейерного допроса в камере иркутской тюрьмы 21 августа 1938 г. 
коведа П. Я. Черных, филологов С. Ф. Баранова и А. В. Гуревича, математика И. Н. Руковицына. Бо́льшая часть исследований касалась школьных проблем, а также методики преподавания учебных предметов. С. Ф. Баранов, В. Д. Кудрявцев, Я. Е. Булдаков, Г. Ф. Кунгуров написали учебные книги для начальной школы, П. П. Михалев - учебную книгу по естествознанию, М. А. Гудошников - учебник по истории СССР.

Главное внимание на историко-филологическом фракультете тех лет уделяли совершенствованию преподавания, учебно-методической работе. В процесс обучения внедрялись элементы краеведения, новейшие достижения исторической науки, приемы и методы ее преподавания. Старейшие и опытные преподаватели всегда щедро делились опытом с молодыми [14]. Активная научная работа профрессорско-преподавательского состава института вносила позитивные изменения в научное творчество студентов, которые в те годы, по воспоминаниям педагогов, отличались высоким уровнем самоорганизации.

В 1937 г. из Иркутского университета перешел на работу в педагогический институт Сергей Владимирович Шостакович - крупный российский специалист по мировой истории и международным отношениям [15]. Он преподавал ряд дисциплин всеобщей истории ${ }^{11}$ и возглавлял одноименную кафедру, читал также историю Древнего мира. Как вспоминают студенты последующих выпусков: «Он завораживал студенческую аудиторию глубоким знанием предмета, ораторским мастерством, владением восточными языками и умением как-то по-особому красиво писать на доске... воплощал в себе подлинную человеческую интеллигентность» [16]. Из сохранившейся в личном деле зачетной книжки мы знаем, что Б. Ширендыб историю Древнего мира у профессора С. В. Шостаковича сдал на отлично и занимался углубленным изучением предмета факультативно.

Доцент Ольга Ильинична Кашик читала курс истории Средних веков ${ }^{12}$. В воспоминаниях студентов она запечатлена как педагог, любящий свой предмет. Чувствовалось, что Ольга Ильинична много готовится к лекциям,

${ }^{11}$ С. В. Шостакович занимался изучением вопросов русско-иранских отношений в XIX в., истории сопредельных с Россией стран Дальнего Востока (Монголия и Китай), проблем античной истории. Докторскую диссертацию посвятил дипломатической деятельности А. С. Грибоедова.

${ }^{12}$ С 1953 г. О. И. Кашик заведовала кафедрой всеобщей истории. Вместе с другими членами кафедры истории подготовила хрестоматию по истории Сибири. которые выделялись содержанием и формой [16].

В 1937-1938 гг. на фракультете стали преподавать несколько видных ученых. В 1937 г. на кафедре литературы начал работать Э. П. Зиннер (с 1940 г. заведующий кафедрой литературы ИГПИ) ${ }^{13}$. С 1938 г. заведующим кафедрой педагогики пединститута назначен видный ученый профессор Михаил Васильевич Одинцов. Психологию на факультете читал М. Ф. Беляев ${ }^{14}$, а пе-

13 Эрвин Петрович Зиннер (25 июля 1912 г., Санкт-Петербург — 21 сентября 1987 г., Иркутск) доктор филологических наук, профрессор, проректор по науке Иркутского государственного педагогического института, заслуженный деятель науки Российской Федерации. Окончил фракультет языка и литературы Ленинградского университета, был направлен на работу в Томск. С 1934 по 1937 г. проходил аспирантуру под руководством академика М. П. Алексеева в Ленинградском пединституте им. А. И. Герцена. Защитил кандидатскую диссертацию. В 1944 г. репрессирован. Во время ареста диссертация была утрачена. 11 апреля 1955 г. Центральная комиссия по пересмотру дел на лиц, осужденных за контрреволюционные преступления, дело в отношении Э. П. Зиннера прекратила. В 1955 г. Э. П. Зиннер вернулся в Иркутск. Совмещая работу декана факультета, чтение курсов лекций по зарубежной литературе с научными исследованиями в области сравнительного литературоведения, Э. П. Зиннер в короткий срок написал и в 1963 г. защитил докторскую диссертацию. Тогда же он стал проректором по науке ИГПИ. Перу Э. П. Зиннера принадлежит около 50 работ, среди них главы коллективной монографии «Шекспир и русская культура», изданной под редакцией академика М. П. Алексеева, труды о связи творчества Л. Толстого с английской литературой, книги о западных ученых - исследователях Сибири, статьи о необходимости сохранения культурного наследия, в частности иркутского деревянного зодчества.

14 Михаил Федорович Беляев (1880-10.11.1955) профессор, доктор психологических наук, кавалер ордена Ленина. Выпускник Московской духовной семинарии со степенью кандидата богословия, магистр философии. С 1916 по 1920 г. преподавал психологию, логику и педагогику в Иркутском учительском институте и читал лекции на педагогических курсах в госуниверситете и пединституте. С 1921 по 1931 г. работал на педфаке ИГУ. Был членом Общества языка, литературы и искусства, созданного на педагогическом фракультете и преобразованного в 1927 г. в Научное общество философии, литературы и социологии. С 1931 по 1955 г. преподавал в Иркутском пединституте. До 1936 г. Михаил Федорович заведовал кафедрой педологии. С октября 1938 г. возглавил кафедру педагогики и психологии. Исследовал психологическую проблему интереса, защитил по ней диссертацию кандидата педагогических наук (1938) и продолжал работать над докторской диссертацией. В предвоенные годы читал лекции по педагогике и психологии в открытом при пединституте родительском университете. В 1945 г. защитил докторскую диссертацию по теме «Психология интереса». Работал в должности профрессора. Активно занимался научной работой. Разрабатывал проблемы интереса к труду у передовых рабочих и колхозников, ступеней развития интереса у школьников. Изучал вопросы нравственного воспитания школьников, психологию формирования моральных убеждений и морального поведения личности. 
дагогику - доцент В. Н. Травлинский. Курс теории литературы вел Гавриил Филиппович Кунгуров ${ }^{15}$. Вот что пишет об этом Э. А. Новгородова: «На лекциях и занятиях литературного кружка писателя Г. Ф. Кунгурова укрепился интерес Ширендыба к литературе и литературному творчеству, выработались строгий вкус и широта взглядов» $[11, \text { с. } 87]^{16}$. В дальнейшем они неоднократно виделись с Б. Ширендыбом в Монголии ${ }^{17}$.

В те далекие годы среди преподавателей было значительное число совместителей: профессора и доценты С. Ф. Баранов, С. В. Шостакович, Ф. А. Кудрявцев ${ }^{18}[17]$, Г. В. Тропин,

15 Гавриил Филиппович Кунгуров (1903-1981) российский писатель, журналист, краевед, педагог, общественный деятель. Член Союза писателей СССР. Доктор филологических наук, профессор ИГПИ. Родился в семье железнодорожника. В 1924 г. окончил Сретенскую учительскую семинарию, в 1928 г. - Иркутский государственный университет. Работал учителем, директором школы, возглавлял Иркутское крайоно. С 1937 г. работал на кафедре литературы Иркутского государственного педагогического института. С 1957 по 1962 г. был ответственным секретарем Иркутской писательской организации. Перу Г. Ф. Кунгурова принадлежат научные статьи и очерки «Ранние культурные и литературные интересы в Сибири», «Белинский о писателях-сибиряках», «Певец окраин милой Отчизны», книга «Сибирь и литература». Первая повесть для детей («Топка») появилась в 1935-м, затем последовали исторические повести «Артамошка Лузин» (1937), «Путешествие в Китай» (1939), вышедшая позже в Москве под названием «Албазинская крепость» (1959). В годы войны Г. Ф. Кунгуровым были написаны книги очерков "С подарками на фронт», «Тыловые рассказы», в 1947-м - повесть «Свет не погас», книги о людях и детях Монголии «Золотая осень», «Оранжевое солнце» и др. Г. Ф. Кунгуров - автор романов «Наташа Брускова», “Светлеют далекие горы». Книги писателя издавались в Иркутске, Москве и за рубежом.

${ }^{16}$ К этому времени у Г. Ф. Кунгурова уже было опубликовано несколько рассказов. Вообще жизнь и творчество Г. Ф. Кунгуров тесно связаны с Монголией, он интенсивно работал над вопросами истории ее культуры. Им опубликован на русском и монгольском языках цикл очерков и рассказов о Монголии и научная статья "Современная монгольская литература». Но интерес профрессора Г. Ф. Кунгурова не ограничивался только литературой. Помимо этого, им был собран материал по истории монгольской революции 1921 г. и в соавторстве с И. А. Сороковиковым была опубликована (1946), а после и переиздана (1957) книга «Аратская революция. Исторический очерк». В 1939-1940 гг. Г. Ф. Кунгуров принимал участие в военных событиях на Халхин-Голе в качестве политработника в рядах Красной Армии.

17 Летом 1943 г. Г. Ф. Кунгуров принимал участие в празднике Надам по приглашению монгольской стороны. Подобные поездки будут предприняты не раз, в личном деле в архиве Иркутского пединститута хранятся пригласительные телеграммы.

18 Федор Александрович Кудрявцев (5 ноября 1899 г., с. Олонки Иркутской губернии - 26 апреля 1976 г., Иркутск) - историк, доктор исторических наук, профессор, один из основателей иркутской исторической школы. В 1909-1918 гг. обучался в иркутской гимназии; в 1920-1924 гг. - на педагогическом фра-
Г. С. Мальцев, М. А. Гудошников ${ }^{19}$ и др. одновременно работали в нескольких вузах. Возможно, причиной этому послужила острая нехватка квалифицированных кадров.

Во время учебы Б. Ширендыб жил в общежитии Иркутского педагогического института. За обучение в институте и проживание в общежитии нужно было платить. Начиная с 1 января 1940 г. Монголия берет на себя ответственность принять половину расходов на обучение и содержание учащихся из $\mathrm{MHP}^{20}$. Это же подтверждено документами из личного дела Б. Ширендыба: «На 4 курсе Б. Ширендыб был освобожден от платы за обучение за вторую половину $1940 / 41$ учебного года» ${ }^{21 .}$

В эти годы происходила передача культовых сооружений институтам и предприятиям города. Студенты исторического факультета, педрабфрака и подготовительных курсов жили в здании бывшей церкви, перестроенной под нужды общежития. Обстановка в комнатах была скромной, даже в чем-то

культете Иркутского университета; в 1924-1929 гг. преподаватель Верхнеудинской школы, секретарь Бурят-Монгольского научного общества им. Д. Банзарова. Впоследствии инструктор архивного управления республики, директор исторического архива Восточно-Сибирского краевого управления. В 1937 г. был арестован НКВД и обвинялся по ст. 58. С 1941 г. преподавал на историко-филологическом факультете Иркутского университета. В 1942 г. защитил кандидатскую диссертацию «История бурят-монгольского народа: Очерки». В 1971 г. защитил докторскую диссертацию на тему «Вопросы экономического развития и социальных отношений в Сибири в XVIII-XIX вв.». С 1956 по 1962 г. работал заведующим кафедрой истории СССР. В 1961 г. ему присвоено звание профессора. Исследовал историю бурятского народа и русского населения края, историю сибирской промышленности, революционного движения в Сибири, военно-патриотическую тематику, историю Иркутска. Один из инициаторов и авторов «Истории Сибири». Долгие годы возглавлял Иркутское отделение общества советско-монгольской дружбы.

19 Моисей Андреевич Гудошников (1 сентября 1894 г., с. Пушкино Саранского уезда Пензенской губернии - 18 июля 1956 г., Иркутск) - историк, профрессор. После окончания Института красной профессуры в 1930 г. приехал в Иркутск в качестве ректора Коммунистического университета. Ректором работал недолго, стал преподавать и возглавил кафедру истории СССР в Иркутском пединституте. Автор более 40 публикаций, в том числе монографии "Очерки по истории гражданской войны в Сибири» (Иркутск, 1959), «Сибирь. Историческая хрестоматия» (Москва; Иркутск, 1932). В 1938 г. был арестован по ст. 58, в 1939 г. его выпустили «без предъявления обвинений». В 1941 г. защитил в Московском университете кандидатскую диссертацию «Общественно-политические взгляды Н. М. Ядринцева». Подготовил докторскую на тему «История как предмет преподавания в средней школе». Публиковался в местных и центральных журналах, в Большой советской энциклопедии, являлся одним из редакторов и авторов Сибирской советской энциклопедии.

${ }^{20}$ URL: http: / /embassymongolia.ru/?page_id=1905\& lang $=\mathrm{ru}$.

${ }^{21}$ ГАИО. Ф. р-842. Оп. 2. Д. 96. Л. 7. 
аскетичной. В комнате вместе с Б. Ширендыбом проживало еще четыре человека. Водопровода и центрального отопления в общежитии не было: в каждой комнате стояла печь, студенты сами носили воду, дрова. Для Б. Ширендыба это не было сложным, поскольку к труду он был приучен с детства.

Трудолюбивый, внимательный к мелочам, и, как отмечали педагоги и будущие коллеги, даже в чем-то дотошный, любознательный и напористый, студент практически не имел свободного времени. Б. Ширендыб хорошо успевал по предметам, что отмечено в его характеристике, которая была выдана 2 декабря 1940 г. ${ }^{22}$ Правда, в ней годом его рождения ошибочно назван 1914-й.

Во время учебы Б. Ширендыб читал произведения классиков и советских писателей, что, несомненно, помогло ему в овладении русским языком. Также тщательно он изучал труды по истории народов мира, методологические произведения по марксизму-ленинизму. Э. А. Новгородова упоминает в своей монографии: "Он с увлечением читал греческого географа Страбона, историю Лависа и Рамбо, труды русских историков» [11, с. 85]. Изучая древнейшие земледельческие цивилизации, он уделял особое внимание истории скотоводческих цивилизаций. Из всех предметов выделял историю Древнего мира ${ }^{23}$. Педагоги-историки рассказывали о проблемах происхождения и специфике кочевой цивилизации Центральной Азии. Эти вопросы были мало изучены и «еще ждали своих исследователей» [11, с. 85]. Он изучал труды П. Карпини, В. Рубрука [18], М. Поло [19], Н. Я. Бичурина [20]. Не остались без его внимания и труды Н. М. Ядринцева, В. В. Радлова [21], Г. Н. Потанина [22; 23], А. Н. Позднеева [24; 25], О. О. Розенберга, Ф. И. Щербатского, В. М. Алексеева, Н. В. Кюнера [26], И. Ю. Крачковского, С. Ф. Ольденбурга, Б. Я. Владимирцова [27]. В этих книгах он находил ответы на вопросы, интересовавшие его с детства. Большое внимание Б. Ширендыб уделял средневековой и новой истории Монголии. Позднее многие его научные труды будут посвящены именно этому периоду.

Б. Ширендыб проявлял интерес к изучению политэкономии, основ марксизма-ленинизма, иностранного языка, педагогики. Хороших результатов он добился, изучая психологию, историю Средних веков, историю СССР, новую историю, русскую литературу, диалектический и исторический мате-

${ }^{22}$ ГАИО. Ф. р-842. Оп. 2. Д. 96. Л. 9.

${ }^{23}$ Там же. Оп. 84. Д. 4176. Л. 9. риализм ${ }^{24}$, методику преподавания истории, историю народов СССР, хорошо знал латинский язык и даже был освобожден от его сдачи во втором семестре ${ }^{25}$. Б. Ширендыб активно занимался научно-исследовательской работой и «был постоянным членом научно-студенческого кружка по истории, которым руководил профессор М. А. Гудошников» [11, с. 87]. М. А. Гудошников вел на фракультете курсы историографии и истории СССР, а также читал краткий курс логики. Его научные интересы отличались многообразием, он увлекался региональной историей, занимался проблемами истории сибирского областничества, писал о революционном движении и гражданской войне в Сибири 26. Ширендыб посещал факультатив по литературе и журналистике Г. Ф. Кунгурова, дополнительно занимался археологией ${ }^{27}$, историей Древнего мира у профессора С. В. Шостаковича. Эти педагоги оказали «большое влияние на формирование мировоззрения молодого Ширендыба» [там же].

По истечении учебных лет каждый выпускник обязательно получал личную характеристику. В характеристике Б. Ширендыба, выданной в декабре 1940 г., отмечены следующие его качества: трудолюбие, выдержанность, дисциплинированность. В ней же говорилось, что он может быть «использован на педагогической работе в высшей школе или на руководящей работе по народному образованию» ${ }^{28}$, и отмечалось успешное прохождение педагогической практики на монгольском языке. После практики его приняли на работу учителем истории в одну из иркутских школ, а затем на подготовительные курсы Иркутского фринансового института для работы с монгольскими студентами. Здесь его характеризовали как хорошего педагога.

Семья Б. Ширендыба на момент его поступления в Иркутский педагогический институт занималась сельским хозяйством в районе Архангая, его старший брат работал сельским кооперативным работником, а три остальных служили в Монгольской народной революционной армии рядовыми ${ }^{29}$.

24 Диалектический и исторический материализм у него читал кандидат философских наук И. И. Шумилов.

${ }_{25}$ ГАИО. Ф. р-842. Оп. 84. Д. 4176. Л. 12.

2624 августа 1937 г. опубликовано постановление жюри правительственной комиссии по конкурсу на лучший учебник для 3-4-х классов средней школы по истории СССР. Иркутский историк доцент пединститута М. А. Гудошников за представленный учебник удостоен поощрительной премии.

${ }^{27}$ ГАИО. Ф. р-842. Оп. 84. Д. 4176. Зачетная книжка № 1134 .

${ }^{28}$ Там же. Л. 9.
${ }^{29}$ Там же. Л. 10. 
Как отмечали родные и знакомые Б. Ширендыба, он очень любил людей, проявлял неподдельный интерес и участие к их судьбам $[28$, c. 72$]$, всегда умел найти тему для разговора [29, с. 23]. Во время учебы в институте Б. Ширендыб принимал участие во многих мероприятиях, регулярно проходивших в актовом зале пединститута, - литературных, творческих вечерах, заседаниях, вечерах памяти, лекциях на актуальные политические темы, творческих юбилеях, вечерах поэтов ${ }^{30}$. На них с докладами выступали преподаватели института, общественные деятели и деятели культуры. Вообще, в то далекое время студенты в перерывах между занятиями выступали с лекциями и беседами перед населением, вели различные кружки в школах, на фрабриках, заводах.

Студентом Б. Ширендыб вместе со своими друзьями С. А. Меркурьевым и Э. А. Шумилевским [13] посещал литературные вечера в институте. Практика проведения таких вечеров сохранилась и в последующие годы. По воспоминаниям выпускников более поздних лет мы можем судить о том, как они проходили. На таких вечерах непременно звучала музыка: студенты сами играли на пианино, которое в учебное время стояло в коридоре и на переменах собирало вокруг себя студентов. Они декламировали литературные произведения, обсуждали новинки культурной жизни города, имели возможность в непринужденной обстановке общаться со студентами разных фракультетов и специальностей. Иногда на таких встречах присутствовали студенты других учебных заведений.

Одновременно с Б. Ширендыбом в Иркутске учился Юмжагийн Цеденбал [30], который в 1938 г. окончил Иркутский фринансовый институт. Они были очень дружны еще со времен совместной учебы на Улан-Удэнском монголрабфаке и в течение 1937-1938 гг. часто встречались, проводили время вместе. Сам Ширендыб-гуай так вспоминал об этом: «Мы, двое монголов, много занимались, свободного времени почти не было, но раз в неделю обязательно встречались. В основном, я ходил к нему; в моей комнате в общежитии

30 Среди них можно отметить творческие вечера писателя Г. Маркова (вечер открыл вступительным словом доцент А. Шурыгин), поэта И. И. Молчанова-Сибирского; заседание, посвященное 750-летию «Слова о полку Игореве» (вступительное слово доцента М. А. Гудошникова); торжественное празднование 20-летнего юбилея Иркутского пединститута; вечер поэтов, на котором выступили К. Седых, А. Ольхон, И. Луговской, И. Молчанов-Сибирский, М. Рыбаков, А. Гайдай, Е. Жилкина, В. Выходцев, И. Черепанов и Е. Яшкин. было пять человек, а ему предоставили отдельную комнату. Не знаю почему, но у Цеденбала уже тогда было привилегированное положение. Мы обменивались монгольскими новостями, обсуждали ситуацию, строилипланы, как ликвидировать в степи неграмотность и ускорить прогресс. Нам обоим предстояло стать интеллигентами в первом колене, и все наши мысли были о просвещении кочевого народа» [30, с. 33].

В 1940 г. на одном из литературных вечеров Б. Ширендыб встретил свою будущую жену - Зинаиду Алексеевну Журавлеву, студентку-заочницу литературного отделения Иркутского педагогического института [13, с. 39].

Окончание учебы и возвращение на родину Б. Ширендыба пришлось на лето 1941 г. Город в связи с нападением фрашистской Германии на Советский Союз и началом войны менялся на глазах. В Иркутске проходили митинги, началась мобилизация, подготовка резервов для действующей армии и фрлота. С началом войны предприятия переходят на военное положение: вводятся сверхурочные работы, отменяются отпуска, усиливаются противопожарные и общие охранные мероприятия ${ }^{31}$. На улицах Иркутска устанавливаются дополнительные громкоговорители, для приема мобилизованных красноармейцев строятся большие землянки с трехъярусными нарами.

Молодежь проходит военное обучение, проводятся ночные походы и военные игры. Из работников искусств создана военно-шефская комиссия для организации концертов и различных культурных мероприятий в воинских частях, госпиталях и на вокзалах ${ }^{32}$.

В такой обстановке в июле 1941 г. после сдачи выпускных экзаменов Б. Ширендыб вместе со своей будущей женой возвратился в Монголию (для этого она, студентка литературного отделения ИГПИ, взяла академический отпуск) $)^{33}$. «В эти годы монгольский народ трудился в ответ на призыв МНРП и правительства MHP: «Все на помощь фронту Отечественной войны советского народа!» [11, с. 89]. Министерство просвещения МНP

31 В пожарных частях созданы группы самозащиты, приведена в боевую готовность пожарная техника, оборудование и инвентарь. Оборудуется светомаскировка, окна оклеиваются бумажными лентами, устанавливаются ящики с песком, развешивается пожарное оборудование.

32 В нее вошли представители Иркутского радио, филармонии, Иркутского областного и Черемховского драматических театров, театров юного зрителя и музкомедии.

${ }^{33}$ ГАИО. Ф. р-842. Оп. 20. Д. 1519. Л. 17-18. 
направило его в Улан-Баторское педагогическое училище, где он должен был вести курс истории Монголии ${ }^{34}$. Для этой работы Б. Ширендыбу приходилось создавать конспекты уроков на основе неопубликованных материалов из архивов и фондов библиотеки [11, с. 90]. Вскоре Б. Ширендыба назначили референтом премьер-министра MHP X. Чойбалсана ${ }^{35}$ по вопросам культуры и просвещения. На этой должности он находился до февраля 1944 г. и всегда сопровождал премьер-министра в поездках в Советский Союз [31]. Таких поездок было немало, поскольку российско-монгольские отношения того периода имели богатую событиями историю. В последующие годы Б. Ширендыб огромное количество раз был в СССР, несколько раз посещал Иркутск, который ввиду непосредственной близости к Монголии и существования тесных культурно-экономические связей Сибири и Монголии превратился в один из традиционных центров монголоведения и подготовки монгольских специалистов [32].

Несомненно, что иркутский период очень важен в биографии известного монгольского академика. Это период становления Б. Ширендыба, включающий в себя четыре года учебы в Иркутском педагогическом институ-

34 Одновременно он был назначен редактором партийного журнала «Намын байгуулалт» («Партийное строительство»), а также председателем бюро внештатных лекторов. Члены этой группы выступали с докладами среди населения.

35 Хорлогийн Чойбалсан (1895-1952) - маршал Монголии. Активный участник монгольской революции 1921 г., командующий войсками в боях на Халхин-Голе в 1939 г. и в военных операциях 1945 г., министр внутренних дел в 1936-1940 гг., премьер-министр с 1939 г. до конца жизни. те - в одном из молодых в то время вузов города. О роли педагогов и их участии в фрормировании личности учащихся сегодня можно найти немало литературы. Нам известно, что в 1930-е гг. в пединституте занятия вели видные деятели науки и культуры, те, кого сегодня считают классиками исторической науки России и Сибири. Не напрасно мы, когда пытаемся охарактеризовать педагогов тех лет, используем слово «плеяда». Они активно трудились, делились опытом и знаниями со студентами.

По признанию самого Б. Ширендыба, педагоги оказали на него сильное влияние, способствовали формированию научных пристрастий и интересов. Связь с преподавателями со своими педагогами из ИППИ, а также из других иркутских вузов он поддерживал на протяжении многих лет. Они проводили совместные исследования, организовывали археологические и этнографические экспедиции, делились опытом. Монгольские вузы и ныне продолжают тесное академическое взаимодействие с вузами Санкт-Петербурга, Москвы, Иркутска и других городов России. Сегодня Монголия занимает одно из первых мест среди других стран по числу специалистов, получивших образование в России. Сотрудничество между нашими странами в этой области было и остается результативным, что дает основание для надежд на развитие взаимодействия в будущем, тем более что конкретных и позитивных примеров более чем достаточно. Список выдающихся политиков, экономистов, ученых Монголии, окончивших вузы Иркутска, довольно объемен и, по сути, представляет современную элиту Монголии.

\section{СПИСОК ИСПОЛЬЗОВАННОЙ ЛИТЕРАТУРЬ}

1. Суходолов А. П. Монголия и русско-монгольские отношения первой половины XX века: проблемы истории и историографии / А. П. Суходолов, Ю. В. Кузьмин ; под науч. ред. М. П. Рачкова. - Иркутск : Изд-во Байкал. гос. ун-та, 2016. - 318 с.

2. Ширендыб Б. Народная революция в Монголии и образование МНР (1921-1924) / Б. Ширендыб. - М. : Изд-во Акад. наук СССР, 1956. - 158 с.

3. Ширендыб Б. Монголия на рубеже XIX-XX веков (История социально-экономического развития) / Б. Ширендыб. - Улан-Батор : Ком. по делам печ., 1963. - 518 с.

4. Суходолов А. П. Российско-монгольские отношения в начале XX века (1900-1921 гг.): экономика, дипломатия, культура / А. П. Суходолов, Б. Болдбаатар, Ю. В. Кузьмин // Известия Иркутской государственной экономической академии. - 2013. - № 6 (92). - С. 92-98.

5. Чимитдоржиев Ш. Б. Б. Ширендыб: учеба на Монголрабфаке (Улан-Удэ) / Ш. Б. Чимитдоржиев // Б. Ширендыб и С. Д. Дылыков в памяти родственников, коллег, друзей / сост. В. В. Грайворонский. - М. : Ин-т востоковедения РАН, 2014. - С. 29-32.

6. Малакшанов К. Л. Иркутский старт монгольских экономистов / К. Л. Малакшанов. - Иркутск : Изд-во БГУЭП, 2006. - 168 с.

7. Болдохонов К. Б. Его девиз: быть первым. Штрихи к портрету академика Б. Ширендыба / К. Б. Болдохонов / / Б. Ширендыб и С. Д. Дылыков в памяти родственников, коллег, друзей / сост. В. В. Грайворонский. М. : Ин-т востоковедения РАН, 2014. - С. 42-54.

8. Гольман М. И. Памяти Б. Ширендыба посвящается / М. И. Гольман / / Б. Ширендыб и С. Д. Дылыков в памяти родственников, коллег, друзей / сост. В. В. Грайворонский. - М. : Ин-т востоковедения РАН, 2014. С. $93-100$. 
9. Грайворонский В. В. Незабываемые встречи с академиком Б. Ширендыбом / В. В. Грайворонский // Б. Ширендыб и С. Д. Дылыков в памяти родственников, коллег, друзей / сост. В. В. Грайворонский. - М. : Ин-т востоковедения РАН, 2014. - С. 61-70.

10. Лиштованный Е. И. Вспоминая об академике Б. Ширендыбе / Е. И. Лиштованный / / Человек на Востоке и Западе: взгляд из Сибири : материалы Междунар. науч. конф., Иркутск, 18 мая 2012 г. — Иркутск : Изд-во Иркут. гос. ун-та, 2012. - С. 75-80.

11. Новгородова Э. А. Сын Хангайских гор / Э. А. Новгородова. - М. : Наука, 1976. - 168 с.

12. Ширендыб Б. Более чем полувековое научное сотрудничество / Б. Ширендыб // Б. Ширендыб и С. Д. Дылыков в памяти родственников, коллег, друзей / сост. В. В. Грайворонский. - М. : Ин-т востоковедения РАН, 2014. - С. 9-20.

13. Хишигт Н. Базарын Ширэндэв / Н. Хишигт / / Монгол Улсын Шинжлэх Ухаан. - Улаанбаатар : Акад. наук Монголии, 2003. - Вып. 3. - 176 с.

14. Иркутский педагогический... / Г. А. Терюшков, В. И. Татаринов, Л. Т. Жученко [и др.] ; ред. В. И. Татаринов [и др.]. - Иркутск : Изд-во Иркут. гос. пед. ин-та, 1996. - 382 с.

15. Шостакович Б. С. Ученый и педагог, общественник и гражданин на культурном перекрестке Востока и Запада: к портрету профессора С. В. Шостаковича в 110-летие со дня его рождения / Б. С. Шостакович // Человек на Востоке и Западе: взгляд из Сибири : материалы Междунар. науч. конф., Иркутск, 18 мая 2012 г. Иркутск : Изд-во Иркут. гос. ун-та, 2012. - С. 4-28.

16. Скретнев Г. И ученик, и учитель... / Г. Скретнев / / Путь к знанию. - 1991. — № 11 (12 дек.).

17. Бильдуева С. В. Профессор Федор Александрович Кудрявцев - исследователь истории Сибири : дис. ... канд. ист. наук : 07.00 .09 / С. В. Бильдуева. - Улан-Удэ, 2005. - 265 с.

18. Карпини И. П. История монголов. Путешествие в восточные страны / И. П. Карпини, В. Рубрук. СПб. : Тип. А. С. Суворина, 1911. - 232 с.

19. Минаев И. П. Путешествие Марко Поло : пер. старофр. текста / И. П. Минаев ; под ред. В. В. Бартольда. - СПб. : Тип. М. М. Стасюлевича, 1902. - 355 с. - (Записки Имп. Рус. геогр. о-ва по отд-нию этнографии ; T. 26).

20. Бичурин Н. Я. Записки о Монголии : в 2 т. / Н. Я. Бичурин. - СПб. : Тип. Карла Края, 1828. - 613 с.

21. Радлов В. В. Этнографический обзор турецких племен Сибири и Монголии / В. В. Радлов. - Иркутск : Изд-во Иркут. гос. ун-та, 1929. - 26 с.

22. Потанин Г. Н. Путешествия Г. Н. Потанина по Монголии, Тибету и Китаю / Г. Н. Потанин ; обраб. М. А. Лялиной. - 2-е изд. - СПб. : Изд. А. Ф. Девриена, 1910. - 247 с.

23. Потанин Г. Н. Тангутско-Тибетская окраина Китая и Центральная Монголия: Путешествие Г. Н. Потанина : 1884-1886 : в 2 т. / Г. Н. Потанин. - СПб. : Имп. Рус. геогр. о-во, 1893.

24. Позднеев А. М. Монголия и монголы: Результаты поездки в Монголию, исполненной в 1892-1893 гг. А. Позднеевым : в 2 т. / А. М. Позднеев. - СПб. : Имп. Рус. геогр. о-во, 1896-1898.

25. Позднеев А. М. Очерки быта буддийских монастырей и буддийского духовенства в Монголии в связи с отношениями сего последнего к народу / А. М. Позднеев. - СПб. : Тип. Имп. Акад. наук, 1887. - 510 с.

26. Кюнер Н. В. География Китая / Н. В. Кюнер. - М. : Изд-во Ин-та востоковедения, 1927. - 78 с.

27. Владимирцов Б. Я. Общественный строй монголов. Монгольский кочевой фреодализм / Б. Я. Владимирцов. - Л. : Изд-во Акад. наук СССР, 1934. - 236 с.

28. Надиров Ш. Г. Его щедрость на внимание к нам была безгранична / Ш. Г. Надиров / / Б. Ширендыб и С. Д. Дылыков в памяти родственников, коллег, друзей / сост. В. В. Грайворонский. - М. : Ин-т востоковедения РАН, 2014. - С. 71-76.

29. Ширендыб Т. Базарын Ширендыб в воспоминаниях родственников. Из воспоминаний Т. Ширендыб / Т. Ширендыб / / Б. Ширендыб и С. Д. Дылыков в памяти родственников, коллег, друзей / сост. В. В. Грайворонский. - М. : Ин-т востоковедения РАН, 2014. - С. 23-25.

30. Шинкарев Л. И. Цеденбал и Филатова: Любовь. Власть. Трагедия / Л. И. Шинкарев. - М. ; Иркутск : Изд. Сапронов, 2004. -528 с.

31. Рощин С. К. Маршал Монголии Х. Чойбалсан: штрихи биографии / С. К. Рощин. - М. : Ин-т востоковедения РАН, 2005. - 160 с.

32. Лиштованный Е. В. Монгольские студенты в Иркутске [Электронный ресурс] / Е. В. Лиштованный // Россия и Монголия. - 2011. - № 3. - Режим доступа: http: / / www.pribaikal.ru/iaz-item/article/9178.html.

\section{REFERENCES}

1. Sukhodolov A. P., Kuz'min Yu. V.; Rachkov M. P. (ed.). Mongoliya i russko-mongol'skie otnosheniya pervoi poloviny XX veka: problemy istorii $i$ istoriografii [Mongolia and Russian-Mongolian Relations in the First Half of the $20^{\text {th }}$ Century: Issues of History and Historiography]. Irkutsk, Baikal State University Publ., 2016. 318 p.

2. Shirendyb B. Narodnaya revolyutsiya v Mongolii i obrazovanie MNR (1921-1924) [The People's Revolution in Mongolia and Education in the Mongolian People's Republic (1921-1924)]. Moscow, Academy of Sciences of the USSR Publ., 1956. 158 p.

3. Shirendyb B. Mongoliya na rubezhe XIX-XX vekov (Istoriya sotsial'no-ekonomicheskogo razvitiya) [Mongolia at the Turn of the $20^{\text {th }}$ Century (History of Social and Economic Development)]. Ulaanbaatar, Press Committee Publ., 1963. 518 p.

4. Sukhodolov A. P., Boldbaatar B., Kuz'min Yu. V. Russian-Mongolian Relations at the Beginning of the $20^{\text {th }}$ Century (1900-1921): Economics, Diplomacy, Culture. Izvestiya Irkutskoi gosudarstvennoi ekonomicheskoi akademii $=$ Bulletin of Irkutsk State Economics Academy, 2013, no. 6 (92), pp. 92-98. (In Russian). 
5. Chimitdorzhiev Sh. B. B. Shirendyb: Studying at the Mongolian Workers' School (in Ulan-Ude). In Graivoronskii V. V. (ed.). B. Shirendyb i S. D. Dylykov v pamyati rodstvennikov, kolleg, druzei [B. Shirendyb and S. D. Dylykov in the Memory of Relatives, Colleagues and Friends]. Moscow, Institute of Oriental Studies of the Russian Academy of Sciences Publ., 2014, pp. 29-32. (In Russian).

6. Malakshanov K. L. Irkutskii start mongol'skikh ekonomistov [The Irkutsk Start of Mongolian Economists]. Irkutsk, Baikal State University of Economics and Law Publ., 2006. 168 p.

7. Boldokhonov K. B. His Motto: To Be the First. Strokes to the Portrait of Academician B. Shirendyb. In Graivoronskii V. V. (ed.). B. Shirendyb i S. D. Dylykov v pamyati rodstvennikov, kolleg, druzei [B. Shirendyb and S. D. Dylykov in the Memory of Relatives, Colleagues and Friends]. Moscow, Institute of Oriental Studies of the Russian Academy of Sciences Publ., 2014, pp. 42-54. (In Russian).

8. Gol'man M. I. Dedicated to the Memory of B. Shyrendyb. In Graivoronskii V. V. (ed.). B. Shirendyb $i$ S. D. Dylykov v pamyati rodstvennikov, kolleg, druzei [B. Shirendyb and S. D. Dylykov in the Memory of Relatives, Colleagues and Friends]. Moscow, Institute of Oriental Studies of the Russian Academy of Sciences Publ., 2014, pp. 93-100. (In Russian).

9. Graivoronskii V. V. Unforgettable Meetings with Academician B. Shirendyb. In Graivoronskii V. V. (ed.). B. Shirendyb i S. D. Dylykov v pamyati rodstvennikov, kolleg, druzei [B. Shirendyb and S. D. Dylykov in the Memory of Relatives, Colleagues and Friends]. Moscow, Institute of Oriental Studies of the Russian Academy of Sciences Publ., 2014, pp. 61-70. (In Russian).

10. Lishtovannyi E. I. The Memoirs of Academician B. Shirendyb. Chelovek na Vostoke i Zapade: vzglyad iz Sibiri. Materialy Mezhdunarnoi nauchnoi konferentsii, Irkutck, 18 maya 2012 g. [Man in the East and the West: Siberian Perspective. Materials of International Scientific Conference. Irkutsk, May 18, 2012]. Irkutsk State University Publ., 2012, pp. 75-80. (In Russian).

11. Novgorodova E. A. Syn Khangaiskikh gor [The Son of the Khangai Mountains]. Moscow, Nauka Publ., 1976. $168 \mathrm{p}$.

12. Shirendyb B. More Than Half a Century of Scientific Cooperation. In Graivoronskii V. V. (ed.). B. Shirendyb i S. D. Dylykov v pamyati rodstvennikov, kolleg, druzei [B. Shirendyb and S. D. Dylykov in the Memory of Relatives, Colleagues and Friends]. Moscow, Institute of Oriental Studies of the Russian Academy of Sciences Publ., 2014, pp. 9-20. (In Russian).

13. Khishigt N. Bazaryn Shirendyb. Mongol Ulsyn Shinzhlekh Ukhaan [Mongolian Science]. Улаанбаатар, Academy of Sciences of Mongolia Publ., 2003. Iss. 3. 176 p. (In Mongolian).

14. Teryushkov G. A., Tatarinov V. I., Zhuchenko L. T. et al. Irkutskii pedagogicheskii... [lrkutsk State Pedagogical.... ]. Irkutsk State Pedagogical Institute Publ., 1996. 382 p.

15. Shostakovich B. S. A Scientist and a Teacher, a Social Activist and a Citizen at the Cultural Crossroads of the East and the West: to the Portrait of S. V. Shostakovich on the $110^{\text {th }}$ Anniversary of His Birth. Chelovek na Vostoke i Zapade: vzglyad iz Sibiri. Materialy Mezhdunarnoi nauchnoi konferentsii, Irkutck, 18 maya 2012 g. [Man in the East and the West: Siberian Perspective. Materials of International Research Conference. Irkutsk, May 18, 2012]. Irkutsk State University Publ., 2012, pp. 4-28. (In Russian).

16. Skretnev G. Both the Student and the Teacher... Put' $k$ znaniyu $=$ The Path to Knowledge, 1991, no. 11 (December 12). (In Russian).

17. Bil'dueva S. V. Professor Fedor Aleksandrovich Kudryavtsev - issledovatel' istorii Sibiri. Kand. Diss. [Professor Fedor Aleksandrovich Kudryavtsev - a Researcher of History of Siberia. Cand. Diss.]. Ulan-Ude, 2005. 265 p.

18. Karpini I. P., Rubruk V. Istoriya mongolov. Puteshestvie $v$ vostochnye strany [History of the Mongols. Journey to the Oriental Countries]. Saint Petersburg, A. S. Suvorin Publ., 1911. 232 p.

19. Minaev I. P., Bartol'd V. V. (ed.). Puteshestvie Marko Polo [The Journey of Marco Polo]. Saint Petersburg, M. M. Stasyulevich Publ., 1902. 355 p.

20. Bichurin N. Ya. Zapiski o Mongolii [Memoirs of Mongolia]. Saint Petersburg, Karl Krai Publ., 1828. 613 p.

21. Radlov V. V. Etnograficheskii obzor turetskikh plemen Sibiri i Mongolii [Ethnographic Survey of the Turkish Tribes of Siberia and Mongolia]. Irkutsk State University Publ., 1929. 26 p.

22. Potanin G. N.; Lyalina M. A. (ed.). Puteshestviya G. N. Potanina po Mongolii, Tibetu i Kitayu [Travel of G. N. Potanin Around Mongolia, Tibet and China]. $2^{\text {nd }}$ ed. Saint Petersburg, A. F. Devrien Publ., 1910. 247 p.

23. Potanin G. N. Tangutsko-Tibetskaya okraina Kitaya i Tsentral'naya Mongoliya: Puteshestvie G. N. Potanina: 1884-1886 [The Tangut-Tibetian Borderlands of China and Central Mongolia: the Journey of G. N. Potanin: 18841886]. Saint Petersburg, Imperial Russian Geographical Society Publ., 1893.

24. Pozdneev A. M. Mongoliya i mongoly: Rezul'taty poezdki v Mongoliyu, ispolnennoi v 1892-1893 gg. [Mongolia and the Mongols: Presenting the results of a trip taken in 1892 and 1893]. Saint Petersburg, Imperial Russian Geographical Society Publ., 1896-1898.

25. Pozdneev A. M. Ocherki byta buddiiskikh monastyrei i buddiiskogo dukhovenstva v Mongolii $v$ svyazi $s$ otnosheniyami sego poslednego $k$ narodu [Essays on the Life of Buddhist Monasteries and Buddhist Clergy in Mongolia and Relations of the Latter to the People]. Saint Petersburg, Imperial Russian Academy of Sciences Publ., $1887.510 \mathrm{p}$.

26. Kyuner N. V. Geografiya Kitaya [Geography of China]. Moscow, Institute of Oriental Studies of the Russian Academy of Sciences Publ., 1927. 78 p.

27. Vladimirtsov B. Ya. Obshchestvennyi stroi mongolov. Mongol'skii kochevoi feodalizm [Social Order of the Mongols. Mongolian Nomadic Feudalism]. Leningrad, Academy of Sciences of the USSR Publ., 1934. 236 p.

28. Nadirov Sh. G. His Generosity of Attention to Us Was Boundless. In Graivoronskii V. V. (ed.). B. Shirendyb $i$ S. D. Dylykov v pamyati rodstvennikov, kolleg, druzei [B. Shirendyb and S. D. Dylykov in the Memory of Relatives, 
Colleagues and Friends]. Moscow, Institute of Oriental Studies of the Russian Academy of Sciences Publ., 2014, pp. 71-76. (In Russian).

29. Shirendyb T. B. Shirendyb in the Memoirs of His Relatives. As Recollected by T. Shirendyb. In Graivoronskii V. V. (ed.). B. Shirendyb i S. D. Dylykov v pamyati rodstvennikov, kolleg, druzei [B. Shirendyb and S. D. Dylykov in the Memory of Relatives, Colleagues and Friends]. Moscow, Institute of Oriental Studies of the Russian Academy of Sciences Publ., 2014, pp. 23-25. (In Russian).

30. Shinkarev L. I. Tsedenbal i Filatova: Lyubov'. Vlast'. Tragediya [Tsedenbal and Filatova: Love. Power. Tragedy]. Moscow, Irkutsk, Sapronov Publ., 2004. 528 p.

31. Roshchin S. K. Marshal Mongolii Kh. Choibalsan: shtrikhi biografii [Mongoliam Marshal Khorloogin Choibalsan: Strokes of Biography]. Moscow, Institute of Oriental Studies of the Russian Academy of Sciences Publ., 2005. 160 p.

32. Lishtovannyi E. V. Mongolian Students in Irkutsk. Rossiya i Mongoliya = Russia and Mongolia, 2011, no. 3. Available at: http://www.pribaikal.ru/iaz-item/article/9178.html. (In Russian).

\section{Информация об авторах}

Суходолов Александр Петрович - доктор экономических наук, профессор, ректор, Байкальский государственный университет, 664003, г. Иркутск, ул. Ленина, 11, e-mail: rector@bgu.ru.

Кузьмин Юрий Васильевич - доктор исторических наук, профрессор, член-корреспондент Академии военных наук, кафедра мировой экономики и международного бизнеса, Байкальский государственный университет, 664003, г. Иркутск, ул. Ленина, 11, e-mail: kuzminuv@yandex.ru.

Куртарева Венера Вячеславовна - аспирант, кафедра истории и методики, Педагогический институт, Иркутский государственный университет, 664011, г. Иркутск, ул. Сухэ-Батора, 9, e-mail: buzaevavv@mail.ru.

\section{Для цитирования}

Суходолов А. П. Иркутский период в жизни академика Базарын Ширендыба / А. П. Суходолов, Ю. В. Кузьмин, В.В.Куфртарева / / Известия Байкальского государственного университета. - 2017. T. 27, № 3. - C. 309-319. - DOI : 10.17150/25002759.2017.27(3).309-319.

\section{Authors}

Alexander P. Sukhodolov - DSc in Economics, Professor, Rector, Baikal State University, 11 Lenin St., 664003, Irkutsk, Russian Federation, e-mail: rector@ bgu.ru.

Yuri V. Kuzmin - DSc in History, Professor, Corresponding Member of the Academy of Military Sciences, Department of World Economics and International Business, Baikal State University, 11 Lenin St., 664003, Irkutsk, Russian Federation, e-mail: kuzminuv@yandex.ru.

Venera V. Kuftareva - PhD Student, Department of History and Methods, Pedagogical Institute of the Irkutsk State University, 9 Sukhe Bator St., 664011, Irkutsk, Russian Federation, e-mail: buzaevavv@mail.ru.

\section{For Citation}

Sukhodolov A. P., Kuzmin Yu. V., Kuftareva V. V. Irkutsk Period in the Life of Academician Bazaryn Shirendyb. Izvestiya Baykal'skogo gosudarstvennogo universiteta = Bulletin of Baikal State University, 2017, vol. 27, no. 3, pp. 309-319. DOI: 10.17150/25002759.2017.27(3).309-319. (In Russian). 